\title{
MASTER
}

(0)y

\section{Biomedical Radioisotope Program, Progress Report for Quarter Ending March 31, 1977}

J. K. Poggenburg
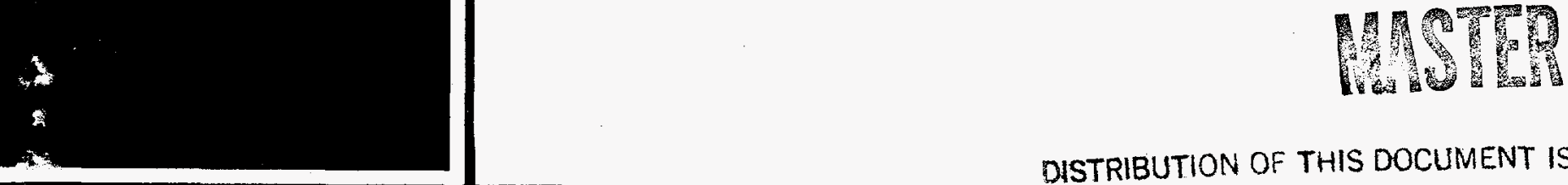
This report was prepared as an account of work sponsored by the United States Government. Neither the United States nor the Energy Research and Development Administration/United States Nuclear Regulatory Commission, nor any of their employees, nor any of their contractors, subcontractors, or their employees, makes any warranty, express or implied, or assumes any legal liability or responsibility for the accuracy, completeness or usefulness of any information, apparatus, product or process disclosed, or represents that its use would not infringe privatelv owned rights. 
Contract No. W-7405-eng-26

HEALTH AND SAFETY RESEARCH DIVISION

BIOMEDICAL RADIOISOTOPE PROGRAM

PROGRESS REPORT FOR QUARTER ENDING MARCH 31 ,

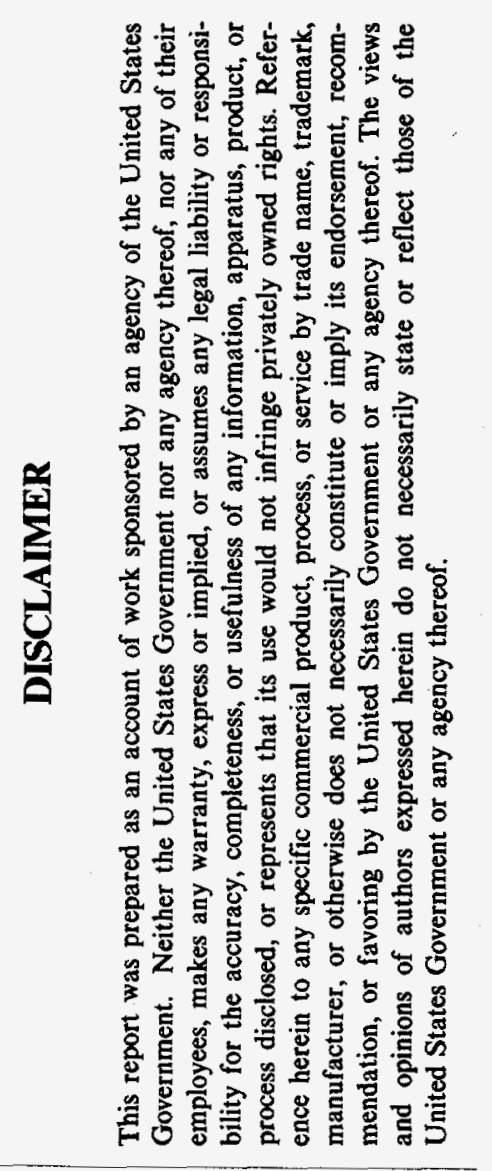

Work sponsored by

ERDA Division of Biomedical and

Environmental Research

J. K. Poggenburg

Date Published - June 1977

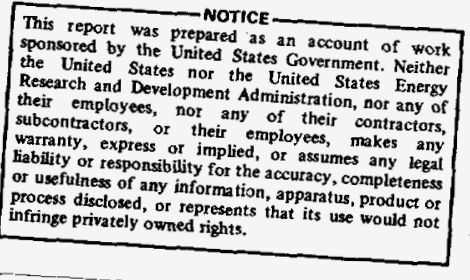

MSTE

NOTICE This document contains information of a preliminary nature.

It is subject to revision or correction and therefore does not represent a

final report.

STRIBUTION OF THIS DOCUMENT IS UNLUMTEI

OAK RIDGE NATIONAL LABORATORY

Oak Ridge, Tennessee 37830

operated by

UNION CARBIDE CORPORATION

for the

ENERGY RESEARCH AND DEVELOPMENT ADMINISTRATION

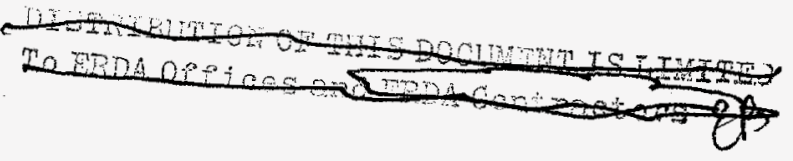


Previous reports in this series:

ORAE/TM-5809 


\section{DISCLAIMER}

Portions of this document may be illegible in electronic image products. Images are produced from the best available original document. 


\section{CONTENTS}

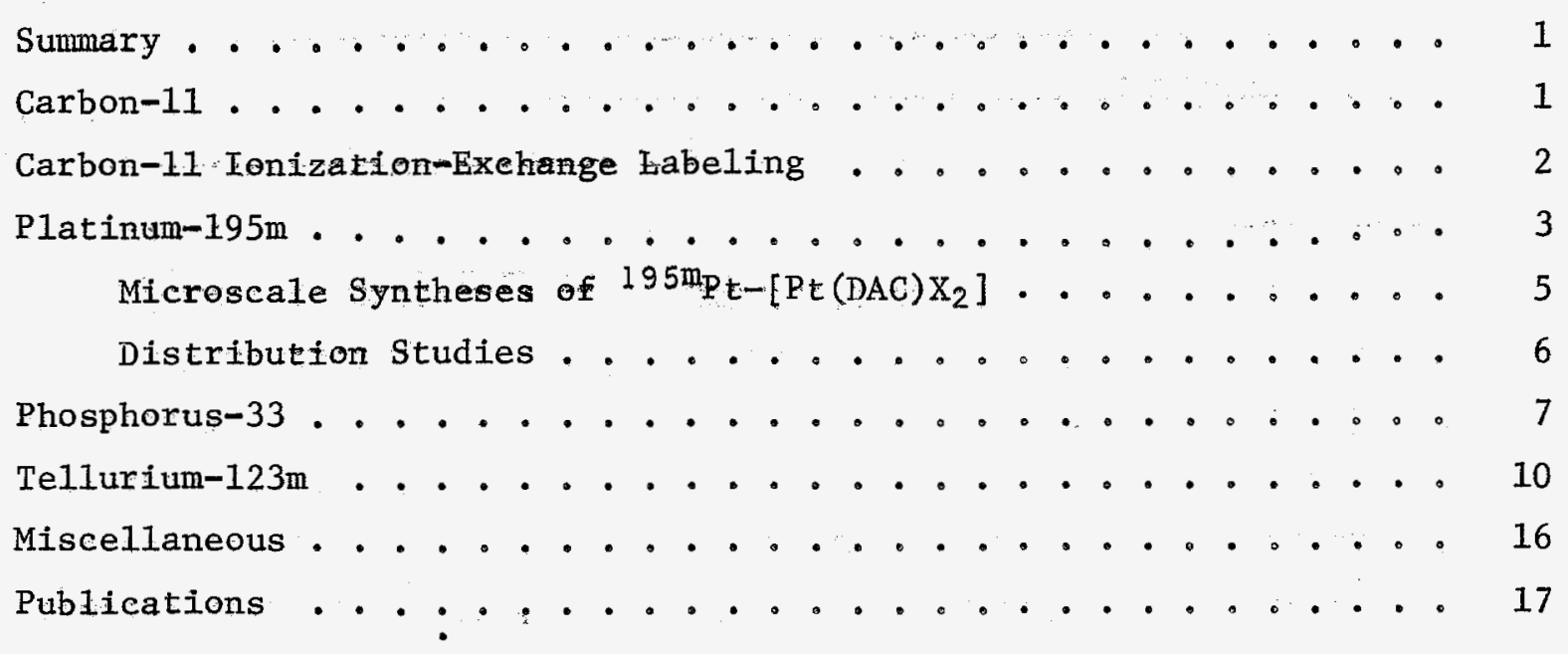




\section{SUMMARY}

Progress is reported for the applications of ${ }^{11} \mathrm{C}, 195 \mathrm{~m}_{\mathrm{Pt}}$, and $123 \mathrm{~m}_{\mathrm{Te}}$. Of note in this report period is the presentation of images of rat adrenals with a $123 \mathrm{~m}_{\mathrm{Te}}$-labeled steriod and an investigation of steroid structural parameters which affect adrenal concentration. Two new $195 \mathrm{~m}$ Pt-labeled compounds have been prepared for evaluation as chemotherapeutic agents.

CARBON-11

T. A. Butzer

Two production runs were made this quarter to study the chemical synthesis of ${ }^{11}$ C-DL-tryptophan for use in the ORAU-ORNL preclinical studies. Carbon-11labeled compound preparation and clinical testing were limited due to a series of malfunctions of the cyclotron which made it inoperable during most of this period.

Equipment was ordered to provide for the synthesis and purification of ${ }^{1} \mathrm{C}$ labeled glucose. The process involves the photosynthetic conversion of ${ }^{11} \mathrm{CO}_{2}$ in light-starved Swiss chard leaves, extraction of ${ }^{1}{ }^{1} \mathrm{C}$-glucose with ethanol and purification by ion exchange.

Design studies are in progress to examine the feasibility of using a flat plate window target for $\mathrm{B}_{2} \mathrm{O}_{3}$ to produce ${ }^{11} \mathrm{CO}^{-1}{ }^{1} \mathrm{CO}_{2}$. A target of this design would allow the full dimensions of the proton beam to impinge on the $\mathrm{B}_{2} \mathrm{O}_{3}$ with the potential of increasing the yield of ${ }^{1}{ }^{1} \mathrm{C}$. 
CARBON-11. IONIZATION-EXCHANGE LABEL ING

$$
\text { D. V. Woo }
$$

Construction of the apparatus described in the last report has continued during this quarter. The cylindrical ionization chamber is constructed of borosilicate glass that can be separated into two sections which are connected by a high-vacuum ground-glass tapered joint with a Viton o-ring. One section contalns two feed-through rods of Kovar which support a thoriacoated tungsten filament across the ends to serve as the electron source. This ionizing filament resembles those used in mass spectrometers. The other section contains a removable stainless steel cylinder supported by two copper rings which position the cylinder concentrically within the glass chamber.

High-vacuum borosilicate glass-teflon valves have been obtained and will be connected to the chamber with high-vacuum ground glass ball joints. These valves will control admission of the $C O$ gas and the vacuum into the chamber. A mercury diffusion pump with freeze trap will be used to evacuate the chamber to approximately $10^{-7}$ torr. This is the estimated vacuum necessary prior to addition of the gases.

The electromagnets for collimating the electron beam have been constructed in four separate sections, to facilitate assembly and removal from the chamber, and have a total rating of approximately 400 gauss. Each section has its own power supply to permit focusing of the beam and adjustments for deviations in magnet geometry and alignment. Appropriate power supplies have been obtained to adjust the electron energy in the unipotential region of the stainless steel cylinder between the filament and collecting plate.

Plans for the next quarter call for assembling the apparatus and checking out individual components for reliability and safety. 


\section{PLAT INUM-195m}

J. D. Hoeschele and T. A. Butzer

As part of the continuing medical cooperative program to study antitumor compounds, five shlpments of $195 \mathrm{~m} \mathrm{pt-hexachloroplatinic} \mathrm{acid} \mathrm{were} \mathrm{made} \mathrm{to}$ the University of Southern California, one shipment of $195 \mathrm{~m}_{\mathrm{Pt}}$-labeled cis$\left[\mathrm{Pt}\left(\mathrm{NH}_{3}\right)_{2} \mathrm{Cl}_{2}\right.$ ] to George Washington University Medical Center, one shipment of 195mpt-labeled [Pt(trans-l-DAC)sulfate] to Wadley Institutes of Molecular Medicine (WIMM), and one shipment of $195 \mathrm{~m} \mathrm{pt-labeled}$ [Pt(trans-l-DAC)malonate] to Mary Hitchcock Memorial Hospital. In addition, each of the latter three 195mpt-labeled compounds was supplied to the ORNL Biology Division for DNA binding studies.

Efforts to optimize the microscale radioisotopic synthesis of $195 \mathrm{mpt-1abeled}$ cis-[Pt $\left.\left(\mathrm{NH}_{3}\right)_{2} \mathrm{Cl}_{2}\right](195 \mathrm{~m} \mathrm{Pt}-\mathrm{DDP})$ are continuing. This optimization, which will be completed in the next quarter, is important in view of the everincreasing interest in $195 \mathrm{~m}_{\mathrm{P}-\mathrm{DDP}}$ and the direct applicability of some of the synthetic steps to planned syntheses.

\section{Microscale Synthes is of cis-[Pt $\left.\left(\mathrm{NH}_{3}\right)_{2} \mathrm{Cl}_{2}\right]$ (0.1 mmole)}

The present microsynthetic scheme for $195 \mathrm{~m}_{\mathrm{Pt}-\mathrm{DDP}}$ is illustrated below by equations (1) to (7):

$$
\begin{aligned}
& \mathrm{Pt}+\text { aqua regia } \stackrel{\Delta}{\rightarrow} \mathrm{H}_{2} \mathrm{PtCl} 6 \\
& \mathrm{H}_{2} \mathrm{PtCl}_{6}+2 \mathrm{NaCl} \frac{\Delta}{\text { dryness }} \mathrm{Na}_{2} \mathrm{PtCl}_{6}+2 \mathrm{HCl} \uparrow \\
& 2 \mathrm{Na}_{2} \mathrm{PtCl}_{6}+\mathrm{N}_{2} \mathrm{H}_{4} \cdot 2 \mathrm{HCl} \stackrel{5-10^{\circ} \mathrm{C}}{\longrightarrow} ; \frac{85^{\circ} \mathrm{C}}{5 \mathrm{~min}} 2 \mathrm{Na}_{2} \mathrm{PtCl}_{4}+\mathrm{N}_{2}+6 \mathrm{HCl} \\
& \mathrm{Na}_{2} \mathrm{PtCl}_{4}+\mathrm{KI}_{\mathrm{xs}} \underset{\text { ambient temp }}{\longrightarrow} \mathrm{K}_{2} \mathrm{PtI}_{4}+2 \mathrm{NaCl}+2 \mathrm{KCl} \\
& \mathrm{K}_{2} \mathrm{Pt} \mathrm{I}_{4}+2 \mathrm{NH}_{3} \underset{\text { ambient temp }}{\longrightarrow} \text { cis-Pt }\left(\mathrm{NH}_{3}\right)_{2} \mathrm{I}_{2} \downarrow+2 \mathrm{KI}
\end{aligned}
$$




$$
\begin{aligned}
& \operatorname{cis}-\mathrm{Pt}\left(\mathrm{NH}_{3}\right)_{2} \mathrm{I}_{2}+2 \mathrm{AgNO}_{3} \frac{\Delta}{50-60^{\circ} \mathrm{C}} \operatorname{cis}-\left[\mathrm{Pt}\left(\mathrm{NH}_{3}\right)_{2}\left(\mathrm{H}_{2} \mathrm{O}\right)_{2}\right]^{2+}, 2 \mathrm{NO}_{3}{ }^{-}+2 \mathrm{AgI}+ \\
& \text { 5-10 min } \\
& \text { cis-[Pt } \left.\left(\mathrm{NH}_{3}\right)_{2}\left(\mathrm{H}_{2} \mathrm{O}\right)_{2}\right]^{2}, 2 \mathrm{NO}_{3}^{-}+\mathrm{HCl}_{x s} \overrightarrow{\sim 50^{\circ} \mathrm{C}} \cdot \operatorname{cis}-\left[\mathrm{Pt}\left(\mathrm{NH}_{3}\right)_{2} \mathrm{Cl}_{2}\right]++2 \mathrm{HNO}_{3}
\end{aligned}
$$

The above synthesis scheme appears little changed from that reported in the previous report (ORNL/TM-5809) but the following modifications have already increased the yields to greater than $50 \%$ with achievement of $60-80 \%$ as the ultimate goal:

Step 2. Addition of $\mathrm{NaCl}$ followed by evaporation to dryness to the thermally stable salt, $\mathrm{Na}_{2} \mathrm{PtCl}{ }_{6}$, rather than to the less stable $\mathrm{H}_{2} \mathrm{PtCl} \mathrm{Cl}_{6}$ residues, leads to (1) more reliable spectrophotometric assays for platinum, and (2) minimal carry-over (occlusion) of $\mathrm{HCl}$ to Steps 4 and 5 . The second consideration is important since too high an $\mathrm{HCl}$ concentration would prevent $\mathrm{NH}_{3}$ from reacting completely and could retard or limit. the extent of $\mathrm{K}_{2} \mathrm{PtI}_{4}$ formation because of high $\mathrm{Cl}^{-}$concentration.

Step 3. The reduction of $\mathrm{Pt}$ (IV) $\rightarrow \mathrm{Pt}$ (II) proceeds equally as rapidly and smoothly (no $\mathrm{Pt}^{0}$ metal formation) with $\mathrm{Na}_{2} \mathrm{PtCl}_{6}$ as with $\mathrm{H}_{2} \mathrm{PtCl}_{6}$. $\mathrm{K}_{2} \mathrm{PtCl}_{6}$ is no longer being used as the $\mathrm{Pt}$ (IV) starting material for this step. By means of a micro combination $\mathrm{pH}$ electrode, the $\mathrm{pH}$ of the reduced solution is adjusted to $\sim 6$.

Step 4. Studies using stable Pt(II) have established that the use of excess $\mathrm{KI}$, rather than the stoichiometric amount, greatly increases the rate of formation and stability (lifetime) of $\mathrm{K}_{2} \mathrm{PtI}_{4}$ without sacrificing yields. (In fact, some enhancement of yields occurs.) A mole ratio of $I / P t=6.0$, instead of 4.0 for stoichiometric conditions, appears satisfactory. The use of $\mathrm{NH}_{4} \mathrm{I}$ instead of $\mathrm{KI}$ appears promising since the ammonolysis step (5) would, in effect, be moderated by the $\mathrm{NH}_{4}{ }^{+} / \mathrm{NH}_{3}$ buffer system. Relatively high overall yields were obtained for a single preliminary synthesis employing $\mathrm{NH}_{4} \mathrm{I}$. 
An important parameter in optimizing and/or reducing the scale of synthesis is the concentration of platinum, especially at Step 4. It is highly desirable to maintain as high a Pt(II) concentration as possible and, optimally, above $0.1 \mathrm{M}$. At concentrations much below this level, rates become slower and causes of loss through competing side reactions increase. The concentration of $\mathrm{Pt}$ (II) can be maximized (a) by dissolving the $\mathrm{Na}_{2} \mathrm{PtCl}_{6}$ residue in a minimum volume of $\mathrm{H}_{2} \mathrm{O}$ after Step 2, and (b) by concentration by evaporation using an air stream during the elevated temperature $\left(85^{\circ} \mathrm{C}\right)$ phase of Step 3 .

Syntheses to date have been carried out on a 0.1 mole scale; however, a 0.05 mole (50 $\mu$ mole) scale is feasible.

Work during the next quarter will focus on:

(1) Quantitating the extent of reduction of $\mathrm{Pt}(\mathrm{IV}) \rightarrow \mathrm{Pt}$ (II).

(2) Completing the remaining parametric studies outlined in the previous report.

(3) Establishing the chemical purity of the product by spectroscopic and chromatographic techniques.

(4) Examining an alternative mode of synthesis via the following reaction scheme:

$$
\mathrm{Na}_{2} \mathrm{PtCl}_{4}+\mathrm{NH}_{4} \mathrm{C}_{2} \mathrm{H}_{3} \mathrm{O}_{2} \frac{\text { reflux }}{1.5 \mathrm{hr}} \text { cis-DDP }
$$

Microscale Syntheses of $195 \mathrm{~m}_{\mathrm{Pt}-\left[\mathrm{Pt}(\mathrm{DAC}) \mathrm{X}_{2}\right]}$

$$
\mathrm{X}_{2}=\text { sulfate and malonate }\left(\mathrm{C}_{3} \mathrm{H}_{2} \mathrm{O}_{4}{ }^{2}\right) ; \text { DAC }=\text { trans-l-1,2-diaminocyclohexane }
$$

Microscale syntheses ( 0.1 mmole) of two closely related potential second generation antitumor $\mathrm{Pt}$ (II) drugs were developed in conjunction with Medical Cooperative Programs established with the Wadley Institutes of Molecular Medicine (Dallas, TX) and the Mary Hitchcock Memorial Hospital (Hanover, NH). 
These $195 \mathrm{mpt}-1 \mathrm{abeled}$ compounds are being used for uptake distribution studies in rats, and in the case of the malonate analog, for eventual combinational therapy (with radiation) vs a brain tumor model system in the rat. Both compounds have been entered into Phase I clinical studies at WIMM.

Methods of synthesis of these compounds are almost identical as outlined below:

Synthesis of $\left[\mathrm{Pt}(\mathrm{DAC}) \mathrm{X}_{2}\right]$

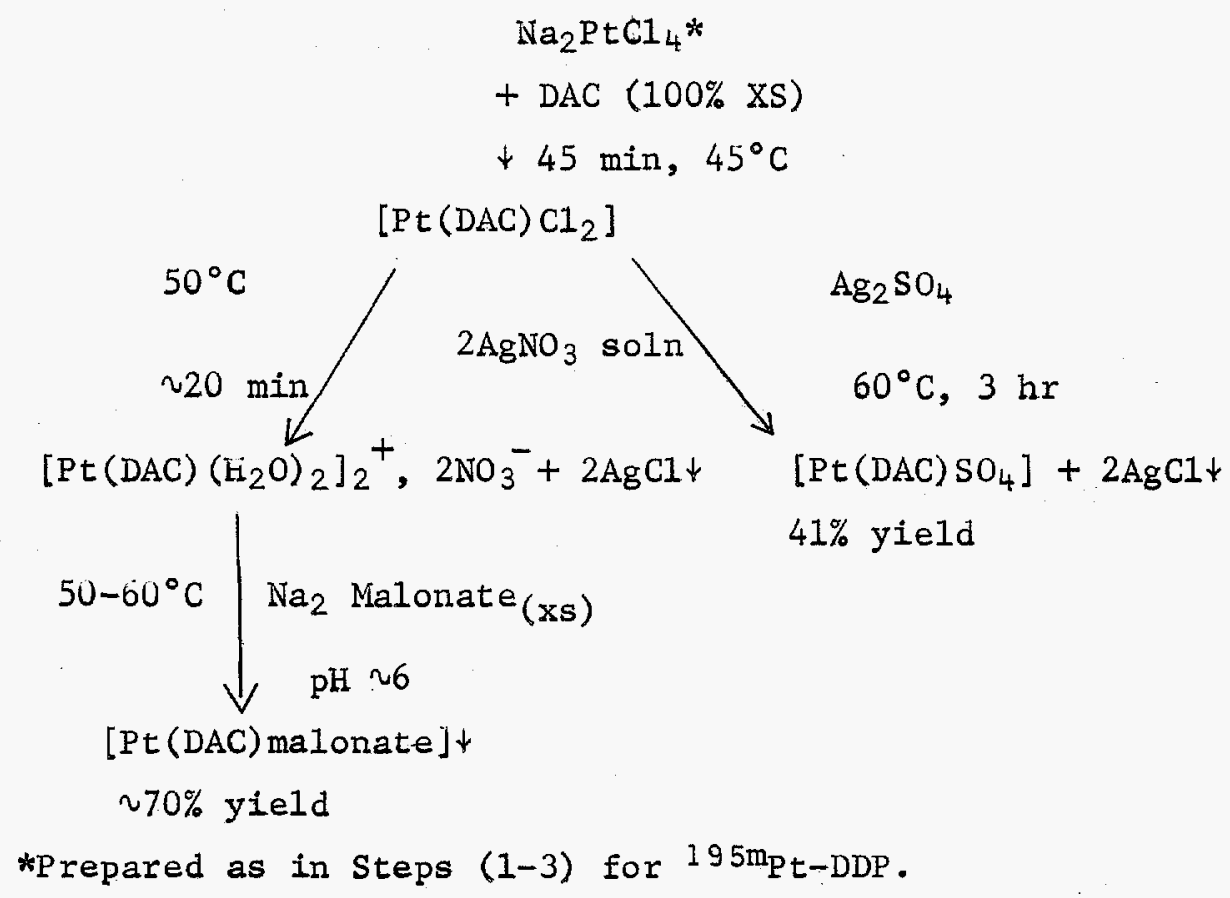

\section{Distribution Studies}

In general, organ distribution studies will be carried out for each new

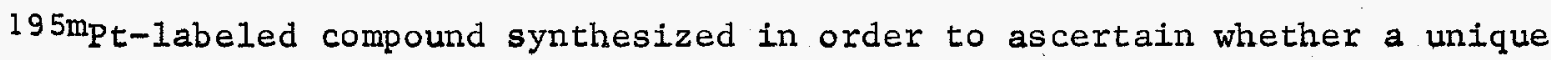
tissue distribution exists which might suggest therapeutic and/or diagnostic applications. These limited studies might also provide a basis of comparing different preparations of the same compound at a later date. 
A comparison of the distribution of [Pt(trans-l-DAC) malonate] and [Pt(transl-DAC) sulfate] in the rat (Fisher 344 ) after $24 \mathrm{hr}$ is shown in Table 1 . General comments are as follows:

(1) The data for the malonate were particularly valuable to E. Douple (Mary Hitchcock Memorial Hospital) in planning his initial experiments, i.e., in terms of the amount of activity to be injected to determine uptake in the brain. Reported levels of platinum uptake in the brain $(>1 \%)$, as determined by atomic absorption spectroscopy, are siginificantly higher than those obtained here and by Douple by radiochemical methods.

(2) The relative order of uptake (\% dose/g tissue) for the malonate is kldney $>$ spleen $>$ pancreas $>$ liver $>$ lung $>$ s. Intestine $>$ heart $>>$ brain, while that for the sulfate analog is

kidney $>$ blood $>$ spleen $>$ liver $>$ lung $>$ s. intestine $>$ pancreas $>$ heart $>$ testes > brain.

Noteworthy is the relatively higher uptake by the pancreas for the malonate compared to the sulfate.

(3) The relatively high blood level ( $1 \%$ dose/ml) remains constant, according to the Wadley group, from 20 min to 7 days post-injection.

PHOSPHORUS-33

D. V. Woo and A. F. Rupp

Construction of the inert atmosphere glove box has been completed. The system is now being tested for leaks, and operational procedures are being developed to comply with safety and quality assurance requirements.

A microscale in situ process has been developed for synthesis of highspecific activity ${ }^{33} \mathrm{p}$-labeled cyclophosphamide. Reactions on a scale of one millimole have been conducted. The reaction scheme involves generation of the bis-(2-chloroethyl)-phosphoramide dichloride in dichloromethane followed by the careful addition of 3-amino-1-propanol and triethylamine. The reaction between bis-(2-chloroethyl) phosphoramide dichloride and 3-amino-1-propanol releases $\mathrm{HCl}$, and consequently, addition of the 3-amino1-propanol must be done in the presence of triethylamine base in order to 
Table 1. Distribution Studies: $\operatorname{Pt}($ trans-l-DAC $) \mathrm{X}_{2}$ in the Rat

(21-24 Hours)

Experimental Details

Dose: Chemical
Activity

Medium

Route of injection

Sacrifice (post-injection)

Animal

Distribution Data

Organ

Brain

Cerebrum
Cerebellum
Medulla

Medu11a

Heart

S. Intestine

Kidney

Liver

Lung

Pancreas

Testes

Spleen

Blood

$\sim 3.7 \times 10^{-5}$
$<6.1 \times 10^{-5}$
$<6.1 \times 10^{-5}$
0.595
0.795
4.26
0.987
0.911
1.69
-
2.07

-
$\mathrm{X}_{2}=$ Malonate

$\mathrm{X}_{2}=$ Malonate

$1.84 \mathrm{mg} / \mathrm{kg}$

$12.85 \mu \mathrm{Ci} /$ anima 1

Saturated solution $(2.5 \mathrm{ml})$

i.p.

$21 \mathrm{hr}$

Fisher $344,320 \mathrm{~g}$.
$\mathrm{X}_{2}=$ Sulfate

$5.83 \mathrm{mg} / \mathrm{kg}$

$371 \mu \mathrm{Ci}$ /anima1

v $0.347 \mathrm{ml}$ of $3.55 \mathrm{mg} / \mathrm{ml}$

i.v.

24

Fisher 344, $211 \mathrm{~g}$

nanomoles/ \% dose/ $/ \mathrm{g} \mathrm{Pt/}$

$\mathrm{g}$ tissue $\mathrm{g}$ tissue $\mathrm{g}$ tissue

nanomoles/

$\%$ dose/g tissue (WIMM*)

$\mu \mathrm{g} \mathrm{Pt/}$

$\mathrm{g}$ tissue

_. (WIMM*) g tissue

$$
0.441 \quad 0.0145(0.022) \quad 0.0861
$$

$2.57 \times 10^{-3}$
$<4.3 \times 10^{-3}$
$<4.3 \times 10^{-3}$
0.0416
0.0556
0.298
0.0690
0.0637
0.118
-
0.147

$\sim 0.007$

$<0.012$

$<0.012$

0.108

0.155

0.831

0.193

0.178

0.329

0.405

$$
\begin{array}{ll}
0.189 & (0.096) \\
0.159 & (9.161) \\
1.56 & (1.07) \\
0.428 & (0.375) \\
0.340 & (0.279) \\
0.108 & (0.098) \\
0.047 & (0.068) \\
0.927 & (0.557) \\
0.953 & (0.96)
\end{array}
$$

1. 12

0.944

9.27

2.54

2.02

0.642

0.279

5.51

5.66

* Results obtained by the Wadley Institutes of Molecular Medicine using identical $\left.{ }^{195 m_{1}} \mathrm{Pt}_{-[\mathrm{Pt}}(\mathrm{DAC}) \mathrm{SO}_{4}\right]$ solution (Sprague-Dawley Rat, $180 \mathrm{~g}$, i.v. $200 \mu \mathrm{Ci}$ ). 
prevent actd hydrolysis of the phosphorus-nitrogen bond and regeneration of the bis-(2-chloroethyl) amine hydrochloride. The crude cyclophosphamide product is recovered from the reaction mixture by evaporation of the solvent, addition of dioxane to precipitate the salts, filtration of the salts, and concentration of the mixture for purification by column chromatography on a silica gel column. The column is eluted with a solvent gradient of decreasing proportions of benzene:acetone. The elution order of products 1s: unreacted bis-(2-chloroethyl)-phosphoramide dichloride, bis-(2-chloroethy1)amine hydrochloride, and finally cyclophosphamide. Any triethy1amine salts which remain on the column are removed with methanol. Experimental yields have not yet been determined. This will be accomplished with ${ }^{32} \mathrm{P}-$ or ${ }^{33} \mathrm{P}-1$ abeled $\mathrm{POCl}_{3}$.

Earlier problems associated with the purification of the bis-(2-chloroethyl)phosphoramide dichloride have been solved using the same column and solvent system. The isolation and purification of this intermediate is not necessary, however, during the synthesis of cyclophosphamide. It is only necessary when it is required as a starting material for other phosphorus compounds with alkylating functions.

Present apparatus and techniques developed for the synthes is of ${ }^{3}{ }^{3}$-labeled phosphorus oxychloride $\left(\mathrm{POCl}_{3}\right)$ from phosphorus pentachloride $\left(\mathrm{PCl}_{5}\right)$ and phosphorus pentoxide $\left(\mathrm{P}_{2} \mathrm{O}_{5}\right)$ have been tested with variable results. Several factors influence the reaction conditions and subsequent yields for this solid-solid interaction. Uneven coating of $\mathrm{P}_{2} \mathrm{O}_{5}$ on the small glass fritted disk in the reactor gives variable yields due to areas in which $\mathrm{PCl}_{5}$ can pass through without reaction. Size, volume, and geometry of the reactor also appear to affect yields. Sublimation of $\mathrm{PCl}_{5}$ to achieve effective interaction with $\mathrm{P}_{2} \mathrm{O}_{5}$ depends upon the rate of argon flow and $\mathrm{Pel}_{5}$ entering the reactor, as well as upon maintaining the correct temperature to distill off the $\mathrm{POCl}_{3}$ free of $\mathrm{P}_{2} \mathrm{O}_{5}$ and $\mathrm{PCl}_{5}$. An alternative procedure has therefore been devised for the reaction of $\mathrm{PCl}_{5}$ with $\mathrm{P}_{2} \mathrm{O}_{5}$ 。 This procedure involves sublimation of $\mathrm{PCl}_{5}$ directly into an inert carrier solvent (carbon tetrachloride, chloroform, or benzene) containing $\mathrm{P}_{2} \mathrm{O}_{5}$ with constant stirring. 
The preliminary experiments in which $\mathrm{PCl}_{5}$ and $\mathrm{P}_{2} \mathrm{O}_{5}$ were reacted in benzene at room temperature to produce $\mathrm{POCl}_{3}$ appear promising. Removal of the POCl $3_{3}$-solvent mixture from unreacted excess $\mathrm{P}_{2} \mathrm{O}_{5}$ was accomplished by simple distillation of the mixture into a receiving vessel. The solvent should have no effect during the synthesis of cyclophosphamide; therefore, the $\mathrm{POCl}_{3}$-solvent mixture can be used directly, or, if need be, the solvent can be separated by fractional distillation.

Plans for the next quarter will include refinement of the cyclophosphamide synthesis, further evaluation and optimization of the two methods for $\mathrm{POCl}_{3}$ production, synthesis of ${ }^{32} \mathrm{p}$ - and/or ${ }^{33} \mathrm{p}-1$ labeled $\mathrm{POCl}_{3}$ for determining yields, and synthesis of high-specific-activity cyclophosphamide for radiolytic decomposition studies.

TELLURIUM- $123 \mathrm{~m}$

F. F. Knapp and $K$. R. Ambrose

We have demonstrated the accumulation of $123 \mathrm{~m}_{\mathrm{Te}}-1$ abeled $3 \beta$-hydroxy-24nor-23-(isopropyl tellura)-5 $\alpha$-cholane in the adrenal glands of male rats following intravenous administration of the labeled compound. More recently, the adrenal glands of both male and female rats have been clearly visualized with both a rectilinear scanner and a camera equipped with an RC-type proportional counter. The latter studies have been performed in conjunction with the Medical Instrumentation Group of the Health and Safety Research Division and the Basic Measurement Science Group of the Instrument and Controls Division, respectively. The ovaries of female rats were also distinctly imaged with this agent. An image of a female rat two days after administration of the labeled compound is illustrated in Fig. 1a. This image was obtained with an RC-proportional counter camera with a xenon gas detector. This method detects the low energy $\mathrm{K}_{\alpha}$ and $k_{\beta} \times$ rays emitted by the $123 \mathrm{~m}_{\mathrm{Te}}$ nuclide. Figure $1 \mathrm{~b}$ is a rectilinear scan obtained on the same animal. The latter system detects both $\mathrm{x}$ rays and the higher energy photons. The image shown was obtained from data collected for the 159-kev gamma photon. 


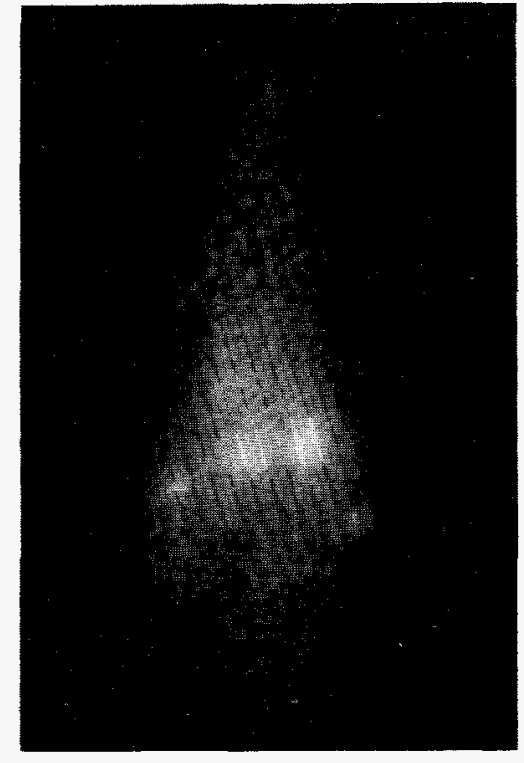

Fig. 1a.

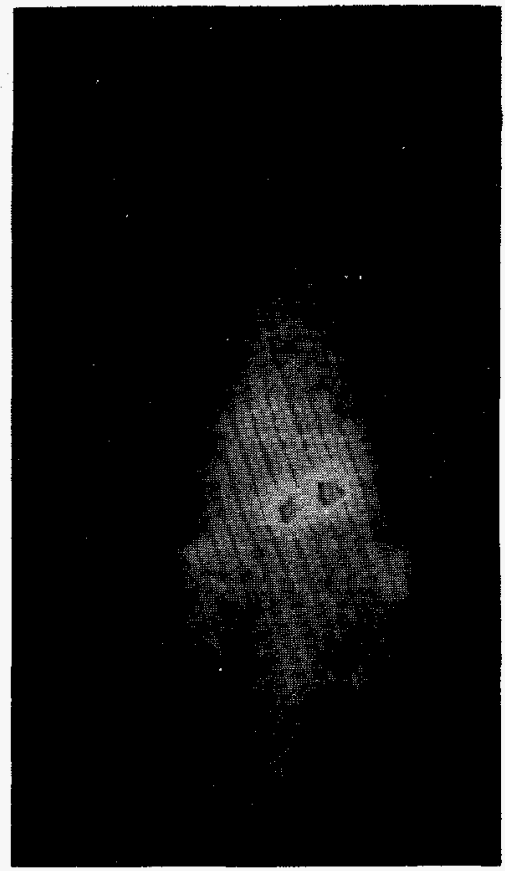

Fig. 1b.

Fig. 1. Posterior views of a female rat two days after the administration of $100 \mu \mathrm{Ci}$ of $123 \mathrm{~m}_{\mathrm{Te}}$-labeled 38 -hydroxy-24nor-23-(isopropy1 tellura)-5 $\alpha$-cholane. The image shown in Fig. 1a was obtained with an RC-type proportional counter camera with a xenon gas detector. The same rat was imaged (Fig. 1b) with a rectilinear scanner equipped with a high resolution gold collimator. In both images the two centrally located Hot (bright) spots are the adrenal glands and the two smaller peripherally located hot spots are the ovaries. 
Tissue distribution studies of intravenously injected $123 \mathrm{~m}_{\mathrm{Te}}-3 \beta$-hydroxy24-nor-23 (isopropyl tellura)-5a-cholane conducted in both male and female Fisher strain rats showed a higher steroid concentration in the adrenals of female rats as compared to males. For example, the adrenal/blood ratios one day after injection were 68 for females and 44 for males. By the seventh day the adrenal/blood ratios were 100 for females and 53 for males.

Distribution studies designed to look at intervals shorter than one day, and also up to three weeks, showed that in male rats the peak concentration of the $123 \mathrm{~m} \mathrm{Te}-1 \mathrm{abeled}$ steroid in the adrenals is reached by $18-24 \mathrm{hr}$ and then slowly declines over the next three weeks (approximately $10 \%$ of maximal concentration remaining at three weeks). Attempts to determine the relative radioactivity in the medulla and cortex of the adrenals were hampered by the small size of rat adrenals. These studies will be done in rabbits.

The combined results of the tissue distribution and scanning studies indicate that $123 \mathrm{~m}_{\mathrm{Te}}-3 \beta$-hydroxy-24-nor-23-(isopropy 1 tellura)-5a-cholane may be useful as an agent for the detector of various adrenal disorders and may also aid in the detection of ovarian tumors and cysts.

The adrenal glands of female rabbits have also been clearly imaged four days after administration of the $123 \mathrm{~m}_{\mathrm{Te}}-1$ abeled steroid using both the rectilinear scanner and a gamma camera. The latter studies were performed in conjunction with the ORAU medical facilities. Neither of the two female rabbits treated with this agent showed ovarian concentration of radioactivity. Without any exceptions the ovaries of female rats have concentrated radioactivity after the injection of this material. It is possible that ovarian uptake is a function of the estrus cycle, which in rabbits is dependent upon coitus.

The adrenal glands and livers of male rats were excised two days after the administration of $123 \mathrm{~m}_{\mathrm{Te}}-3 \beta-h y d r o x y-24-$ nor-23-(isopropy 1 tel1ura)-5acholane. The tissues were Folch extracted and the lipid-soluble portions 
subjected to silicic acid chromatography. The liver extract contained predominantly very polar radioactive components which were eluted from the column in the methanol wash. In contrast, the adrenal extracts contained a number of labeled components. One major component was very nonpolar and was eluted from the column with the expected mobility of steryl esters. An expected metabolic fate of neutral monohydroxy steroids con, centrated in the adrenal gland would be esterification with long-chain fatty acids. The adrenal extract also contained two other major components of moderate polarity which may represent nuclear modifications of the administered compound. These results were reproduced in a separate experiment performed in the same manner. The fact that the tissues were manipulated in the same manner and the radioactive column profiles of the adrenal and liver extracts were consistently different suggests that the radioactive components detected upon silicic acid chromatographic analyses must represent true metabolites of the administered compound. From a biochemical vantage point these results raise several interesting questions, since it is known that the saturated steroid cholestanol is not metabolized by rat adrenal homogenates.

The general scheme that was developed for the introduction of $123 \mathrm{~m}_{\text {Te }}$ into the steroid sidechain is efficient and easily adaptable for the preparation of a wide variety of steroids. These methods are thus uniquely suited for an investigation of the effect of steroid structure on the ability of the adrenal to concentrate such substances. Several structural modifications of the steroid nucleus and sidechain were envisioned which could give a general indication of the structural parameters which determine uptake of steroids by the adrenals. The structural modifications that were investigated include the following: (1) the stereochemistry of the A/B ring juncture, (2) the presence of a hydrophobic C-3 substituent, (3) the effect of the $\Delta^{5}$-nuclear double bond, and (4) the presence of a large alkyl tellurium substituent in the sidechain. The syntheses of representative steroids exemplifying these structural variations are discussed below with results of biological studies with the $123 \mathrm{~m}_{\mathrm{Te}}-1$ abeled steroids. 
(1). During the initial stages of our investigations directed towards the preparation of steroids labeled in the sidechain with $123 \mathrm{~m}_{\mathrm{Te}}, 3 \alpha-$ acetoxy-5B-cholanic acid was chosen as a model substrate to determine the efficacy of the Hinsdiecker degradation to prepare the corresponding 24-nor bromide. This technique resulted in a $32 \%$ yield of the 3a-acetoxy-24-bromo-5B-cholane which was then coupled with sodium isopropyl tellurol in the usual manner to give $3 \alpha$-hydroxy-24nor-23-(isopropyl tellura)-5B-cholane. The $123 \mathrm{~m}_{\mathrm{Te}}-1$ abeled compound was prepared in the same manner. Tissue distributions of the labeled steroid in female rats indicated only minimal adrenal uptake. These results were further substantiated by rectilinear scans of both male and female rats following administration of the labeled analog. The adrenal glands of these rats could not be visualized during the period of up to two weeks after injection. These results indicate that the stereochemistry of the $A / B$ ring juncture is an important structural feature affecting adrenal uptake of such compounds.

(2) and (3) The Hünsdiecker-type degradation was not applicable for the decarboxylation-halogenation of bile acids containing a nuclear double bond. For this reason an alternative procedure was used for the synthesis of the requisite halogenated sidechain intermediate. Methyl-3ß-methoxy-chol-5-en-24-oate was prepared from the methyl ester of the parent compound by reaction with trimethyl orthoformate and perchloric acid. Reduction with methoxy ethoxy sodium aluminum hydride gave 3B-methoxy-24-hydroxy-chol-5-ene which was converted

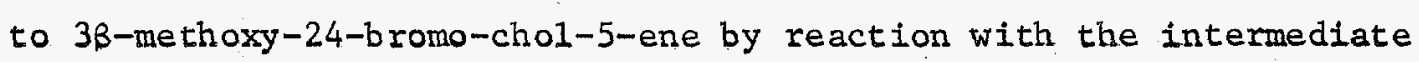
species generated by the reaction of carbon tetrabromide and triphenyl phosphine. The 24-bromide was coupled with sodium isopropy 1 tellurol in the usual manner to yield the $3 \beta$-methoxy-24-(1sopropyl tellura)-chol-5-ene. Tissue distribution experiments with the $123 \mathrm{~m}_{\mathrm{Te}}-1 \mathrm{abeled}$ compound in female rats indicated an adrenal concentration (\% dose/g) lower than that obtained with $123 \mathrm{~m}_{\mathrm{Te}}-3 \beta-h y d r o x y-$ 24-nor-23-(isopropyl tellura)-5a-cholane (24 and 65, respectively). In addition, the concentration in other tissues was high, resulting in only moderate adrenal/tissue ratios (e.g., 5:1 adrenal/1iver). 
These data were corroborated by the rectilinear scans of a rat for periods up to a week after infection with labeled compound. After fifteen days, however, the adrenals and ovaries of a female rat were clearly imaged. These results indicate that certain structural features of the steroid not only determine adrenal uptake but also dictate the rates at which steroids are taken up and cleared by other tissues.

To study the effect of the $\Delta^{5}$-nuclear double bond the $3 \beta$-methoxy24-bromo-cho1-5-ene was converted to 3k-acetoxy-24-bromo-chol-5-ene by reaction with anhydrous ferric chloride in a mixture of acetic anhydride-ethyl acetate. The acetate was then coupled with sodium isopropyl tellurol in the usual manner to yield 3B-hydroxy-24(isopropyl tellura)-chol-5-ene. Although the tissue distribution experiments with the $123 \mathrm{~m}_{\mathrm{Te}}-\mathrm{labeled}$ compound have not yet been initiated, rectilinear scans of both male and female rats following administration of this agent have indicated a very rapid adrenalspecific uptake of this material. These preliminary results suggest that this analog is even more efficient for early visualization of

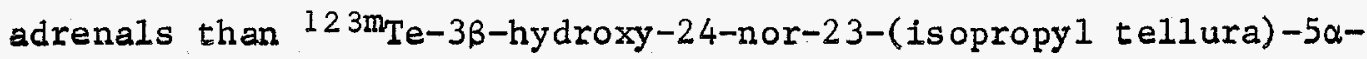
cholane.

(4). To investigate the effect of enlarging the alkyl tellura sidechain substituent, sodium octyl tellurol was prepared by the general

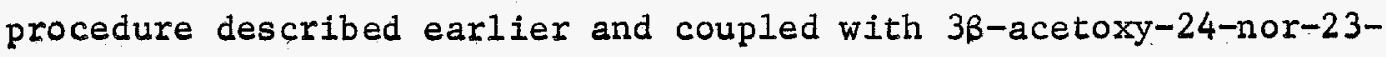

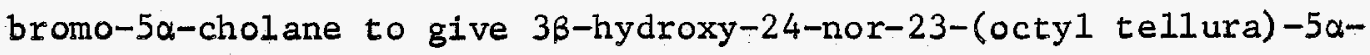
cholane. This interesting analog was fully characterized by the usual methods and the $123 \mathrm{~m}_{\mathrm{Te}}-1$ abeled compound was then prepared. Although tissue distributions of this analog have not been initiated, rectilinear scans of both male and female rats injected with this material have given discouraging results. Even ten days after injection only minimal adrenal uptake could be detected. These results indicate that the steroid sidechain also plays an important role in determining adrenal uptake. 
During the next quarter the factors that affect ovarian uptake of $123 \mathrm{~m}_{\mathrm{Te}}$

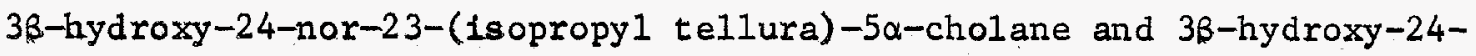
(isopropyl tellura)-chol-5-ene will be investigated. In addition, biological studies of the new compounds described in this report will be completed. These include in vitro incubations of the above two steroids with rat adrenal homogenates. The results of the latter experiments will be compared to those discussed earlier for the adrenal extracts obtained following in vivo administration. In addition, both the in vivo and in vitro experiments will be performed to determine the metabolic fate of the above two $123 \mathrm{~m}_{\mathrm{Te}}$-labeled steroids in ovarian tissue.

\section{MISCELLANEOUS}

Nine shipments of $43 \mathrm{~K}$ were made this quarter. Three shipments to the University of Mississippi were used for radioisotope imaging in heart disease studies in comparison with ${ }^{201} \mathrm{~T} 1$. Three shipments to Brookhaven National Laboratory were used in their studies of exchangeable electrolytes in human subjects. One shipment was made to National Institute for Environmental Health for study of alkali metal ion perfusion in the inner ear of guinea pigs to relate uptake in the endolymph as a function of noise and disease factors. One shipment was made to the City College of New York for imaging studies, and one shipment was made to Argonne National Laboratory for use in chemical studies.

One shipment of high-specific activity ${ }^{64} \mathrm{Cu}$ was sent to ORAU for tumor localization studies. This positron emitter has potential usefulness with their new Emission Computed Axial Tomographic (ECAT) scanner.

$\mathrm{J}$. D. Hoeschele attended a meeting at the University of Vermont Regional Cancer Center concerning the prospective use of $\mathrm{Pt}$ (II) compounds in treating brain tumors (chemotherapy plus radiation therapy). He also presented seminars at both the East Tennessee Section of the American Chemical Society and at ORAU concerning "Platinum Antitumor Complexes in Cancer Chemotherapy." J. K. Poggenburg presented a seminar on "Medical Applications of Radioisotopes" at Union University, Jackson, TN. 
Visitors this period include Dr. Jack Coupal, Radiopharmacist at the V. A. Hospital, Lexington, KY, and Mr. Richard Yanzey, a student in the School of Pharmacy, University of Kentucky, who spent a day learning techniques for the synthesis of $195 \mathrm{mpt-DDP}$.

\section{PUBLICATIONS}

\section{Reports}

J. K. Poggenburg, Biomedical Radioisotope Program Progress Report for Quarter Ending December 31, 1976, ORNL/TM-5809, Oak Ridge National Laboratory (February 1977). 
$\bullet$

i 
ORNL/TM-5936

INTERNAL. DISTRIBUTION

\author{
1. K. R. Ambrose \\ 2. S. I. Auerbach \\ 3. J. A. Auxier \\ 4. J. M. Becker (Consultant) \\ 5. P. R. Be11 \\ 6. C. J. Borkowski \\ 7. T. A. Butler \\ 8. W. R. Casto \\ 9. K. Cowser \\ 10. J. A. Cox \\ 11. D. E. Ferguson \\ 12. R. B. Gammage \\ 13. W. R. Garrett \\ 14. H. N. Hill \\ 15. J. D. Hoeschele \\ 16. S. V. Kaye \\ 17. G. D. Kerr \\ 18. F. F. Knapp, Jr.
}

\author{
19. E. Lamb \\ 20. P. Nettesheim \\ 21. C. L. Ottinger \\ 22-26. J. K. Poggenburg \\ 27. H. Postma \\ 28. M. E. Ramsey \\ 29. C. R. Richmond \\ 30. A. F. Rupp (Consultant) \\ 31. M. R. Skidmore \\ 32. M. J. Skinner \\ 33. J. B. Storer \\ 34. D. V. Woo \\ 35. H. A. Wright \\ 36-37. Central Research Library \\ 38. Document Reference Section \\ 39-40. Laboratory Records Department \\ 41. Laboratory Records, ORNL RC
}

\section{EXTERNAL DISTRIBUTION}

42-43. Technical Information Center, ERDA-ORO, Oak Ridge, TN 37830

44. D. C. Davis, ERDA-ORO, Oak Ridge, TN 37830

45. J. A. Lenhard, ERDA-ORO, Oak Ridge, TN 37830

46. J. N. Maddox, ERDA-DBER, Washington, DC 20545

47. W. H. Weyzen, ERDA-DBER, Washington, DC 20545

48. R. M. Woods, Jr., ERDA-DBER, Washington, DC 20545

49. T. F. Budinger, M.D., Donner Lab., LBL, Berkeley, CA 94720

50. A. J. Girardi, ET Cancer Research Center, UT Hospital, Knoxville, TN 37920

51. R. L. Hayes, ORAU, Oak Ridge, TN 37830

52. C. C. Lushbaugh, ORAU, Oak Ridge, TN 37830

53. H. A. O'Brien, LASI, Los Alamos, NM 87545

54. P. Richards, BNL, Upton, NY 11973

55. A. P. Wolf, BNL, Upton, NY 11973

56. H. E. Walburg, CARL, Oak Ridge, TN 37830

57. A. Solomon, M.D., UT-MRCH, Knoxville, TN 37920

58. A. Legendre, M.D., UT-School of Veterinary Medicine, Knoxville, TN 37920 